Jasminka Zloković

DOI:10.19090/zop.2016.25.7-22

Sveučilište u Rijeci,

UDC:316.356.2:316.47

Filozofski fakultet

Originalni naučni rad

Andrea Lukajić,

Rijeka,

Hrvatska

\title{
OSNAŽIVANJE OBITELJI KROZ POTICANJE POZITIVNIH ODNOSA I OBITELJSKE KOHEZIJE ${ }^{1}$
}

Apstrakt: Rezultati multidisciplinarnih istraživanja pokazuju da međusobna povezanost, potpora, pozitivna obiteljska atmosfera, način i razina komunikacije u obitelji i širem društvenom okruženju mogu da potiču, ali i da osporavaju i ograničavaju razvoj ličnosti. U radu polazimo sa stanovišta pitanja o obiteljskoj komunikaciji i koheziji s ciljem poticanja daljnjih mogućnosti u osnaživanju obitelji a time i pronalaženja konceptualnih modela u podizanju razine pozitivnih obiteljskih odnosa i zdravog razvoja djece.

Rezultati istraživanja, koje se provodilo 2010. i 2016. godine u sklopu znanstvenog projekta „Pedagoški aspekti odnosa u obitelji“ (Zloković, 2012) longitudinalnom primjenom Olsonovog modela kao konceptualnog modela za mjerenje obiteljskog sistema, pokazuju neuravnotežene obiteljske odnose ekstremno visoku i ekstremno nisku povezanost na skali obiteljske kohezivnosti. Visoki rezultati na emocionalnoj povezanosti mogu ukazivati na otežani razvoj buduće neovisnosti individue, a niska povezanost na kaotične odnose u obitelji. I na skali za ispitivanje komunikacije roditelj - dijete pokazuju se također dvije ekstremne skupine ispitanika. Na jednoj strani nalaze se ispitanici čiji odgovori ukazuju na neprimjerenu, nejasnu, ambivalentnu komunikaciju u obitelji i na suprotnom kraju ispitanici koji sa svojim roditeljima komuniciraju na visokoj razini što je jedna od pretpostavki koja pridonosi visokim rezultatima na skali kohezivnosti.

Dobiveni rezultati doprinose pedagoškoj znanosti, posebno obiteljskoj pedagogiji, kao i praksi u određivanju preventivnih i intervencijskih aktivnosti usmjerene na optimalno funkcioniranje i osnaživanje obitelji.

Ključne riječi: obiteljska kohezija, komunikacija, odnosi u obitelji, osnaživanje obitelji.

${ }^{1}$ Jasminka Zloković, jzlokovic@ffri.hr, Andrea Lukajić, lukajic.andrea@gmail.com 


\section{Kompleksnost obiteljskog funkcioniranja}

Istraživanju obitelji kao kompleksnog socijalnog fenomena neminovno je interdisciplinarno pristupiti kao što je evidentna i različitost u definiranju obitelji ovisno o području koje se njome bavi, teorijskom pristupu, kao i o društvenom kontekstu. Različite znanosti usmjerene su na proučavanje razvoja i funkcija obitelji, obiteljskih odnosa, odgoja djece, strukture obitelji, budućnosti obitelji i druga pitanja ključna za njezino bolje funkcioniranje i bolju kvalitetu obiteljskog života. Uz uvažavanje stalne promjenjivosti obitelji kroz vrijeme i uz oprez u odnosu na futurološka istraživanja, obitelj je nenadoknadiv životni i odgojni čimbenik. Činjenica da do danas nije pronađen odgovarajući „nadomjestak” obitelji, kao i da je obitelj još uvijek - s obzirom na njezin utjecaj tijekom životnog ciklusa prva i najvažnija socijalna sredina u kojoj dijete stječe prva znanja, vještine, sposobnosti, navike, te formira stavove prema sebi i okolini, ukazuje na važnost obitelji i kompleksnost obiteljskog funkcioniranja. Obitelj je iznimno moćna temeljna društvena grupa i jedna od najsnažnijih odgojnih sredina, čak i kada odnosi u njoj nisu na očekivano zadovoljavajućoj razini. Prema tradicionalnim i suvremenim teorijama (historijsko-institucionalni, sociološki, strukturalno-funkcionalni, psihološki pristupi, razvojne teorije, ekološka teorija i dr) slijedi da je obitelj živi organizam koji usljed kompleksnih interakcijskih odnosa i utjecaja okoline tijekom vremena doživljava brojne mijene i zahtijeva prilagodbe na nove i drugačije oblike interakcije (Rosić, Zloković, 2002). Činjenica je da provedba interakcija obitelji s drugim sustavima ovisi o uspostavljanju unutarnjih odnosa i propusnosti obiteljskih "granica", pri čemu se može govoriti o prostornoj, emocionalnoj i kognitivnoj propusnosti. Iako je uvjetovan globalnim društvenim sustavom, obiteljski život nije samo odraz ili transmisija društvenih procesa. Organizacija obiteljskog života ne ovisi samo o objektivnim uvjetima, već i o posebnim čimbenicima povezanim sa funkcioniranjem obitelji. Funkcioniranje i odnosi u obitelji u međusobnoj su složenoj interakciji sa socijalnim, gospodarskim, odgojno-obrazovnim, političkim i drugim sustavima. U tim interakcijama nailazi se na mnoge poteškoće i (ne)snalaženja uslijed kojih je realno očekivati profesionalnu savjetodavnu i pravodobnu pomoć (pedagoga, psihologa, socijalnih radnika, učitelja, odgajatelja, ravnatelja odgojno-obrazovnih ustanova i drugih struka) kako bi obitelj što učinkovitije funkcionirala i izvršavala svoje funkcionalne zadaće prvenstveno prema djeci. 
U pedagoškoj literaturi najčešće je isticano shvaćanje koje prisupa obitelji sa stajališta odnosa koji vladaju u njenom neposrednom okruženju - tradicionalna obitelj (patrijarhalno-autoritativni odnosi) i suvremena obitelj (egalitarno-demokratski odnosi). Svaku podjelu treba uzeti s oprezom jer obitelj sa "čistom" tipologijom ne postoji, kao što se i današnje dinamično vrijeme ne odriče "snova o zlatnim obiteljima iz prošlosti" (Zloković, 2007). Ipak, usmjerenost kolektivističkom tradicionalnom stilu života, autoritetu i ugledu pater familiasa slabi. Suvremeno društvo snažno potiče potrebu za individualnom afirmacijom, kompeticijom i potvrđivanjem sposobnosti, osobnih ambicija i želja svakog pojednica, što se odražava i na međusobno oslabjele interakcije u obitelji, slabljenje obiteljske kohezije, međusobno izbjegavanje i uvjerenost u nedostatak zajedničkog vremena. S obzirom na kompleksne probleme s kojima se današnja obitelj suočava (porast ovisnosti, psihosomatskih bolesti, agresivnosti, nasilja, preuranjene seksualne aktivnosti, egzistencijalnih problema i dr), čini se da često na njih nije spremna budući mnogi roditelji ne uspijevaju iznaći prihvatljive odgovore na problem(e). Ovo pravi snažni vakuum u funkcioniranju i uspostavljanju međusobno pozitivnih odnosa, a posljedično niti konfliktne situacije nisu rijetke pojave. U nizu neminovnih promjena nastalih tijekom vremena i procesa modernizacije obitelji, izgleda da je obiteljski život shvaćen kao proces depatrijalizacije i detradicionalizacije života, površnih i oslabljelih međusobnih odnosa i kao slabljenje u izvršavanju roditeljskih funkcija koje žele ići u pravcu strukturne transformacije, kreiranja autonomnog prostora obitelji i uspostavljanja ravnopravnijih i egalitarnijih odnosa među spolovima i generacijama (Milić, 2010). Raznolikost strukture, odnosa, funkcija, načina formiranja i opstojanja obitelji u odnosu na vanjske i unutarnje utjecaje implicira da je svaka obitelj jedinstvena, i da bi u skladu s postmodernim stajalištima za svaku obitelj trebalo kreirati jedinstvenu definiciju (Janković, 2008).

S obzirom na glavni opći cilj ovog rada identificirati neke aspekte odnosa u obitelji, kao što je obiteljska kohezija i komunikacija, ne pretendiramo na širi teorijski prikaz obitelji već ukazujemo na neke različitosti u funkcioniranju tzv. centripetalnih i centrifugalnih obitelji kao dva ekstremna kraja na ljestvici za mjerenje obiteljskog funkcioniranja. Neka djeca s obzirom na obiteljsku koheziju i komunikaciju preuranjeno su prepuštena sama sebi, dok su na drugome kraju njihovi vršnjaci koji žive pod obiteljskim "staklenim zvonom" (Zloković, 2012). Mnoga su 
pitanja koja se mogu postaviti u svezi obitelji i obiteljskog života i odnosa između roditelja i djece. Primjerice, da li unatoč nekim pesimističnim viđenjima o slabljenju međusobnih odnosa u suvremenoj obitelji oni ipak mogu ojačati? Da li sretne i snažne obitelji možemo zaista tražiti samo u prošlosti ili je ipak riječ o imagninaciji? Mislimo li odista da je suvremeno doba istisnulo temeljne funkcije obitelji? Je li moderna obitelj odgojnu funkciju prepustila nekome drugome? Mogu li elektronički posrednici i simulatori obiteljskog života zamijeniti emocionalno bliske odnose i neposredne kontakte između roditelja i djece? Od koga će djeca i mladi naučiti kako steći vlastiti stav, usvojiti temeljne moralne vrijednosti, razviti odgovornost prema sebi i drugim ljudima (Vrcelj, Zloković, 2004) kada se dnevna količina komunikacije i kvalitetnog zajedničkog vremena u obitelji smanjuje na minimum? Čini se mnogo je razloga zbog kojih se današnje obiteljsko vrijeme živi formalno i površno - jedan pokraj drugog - umjesto jedan sa drugim, što implicira međusobno povjerenje i zajedništvo. Međusobna povezanost, potpora, pozitivna obiteljska atmosfera, načini i razina komunikacije u obitelji i širem društvenom okruženju može poticati ili osporavati i ograničavati razvoj ličnosti. Unatoč različitosti u teorijskim i istraživačkim pristupima, međusobni odnosi i obiteljska atmosfera pojavljuju se kao respektabilne dimenzije u ispitivanju kvalitete života, a posebice se ovo odnosi na vrijeme koje roditelji provode sa djecom, prilike za međusobni razgovor i formiranje međusobne kohezije (Zloković, 2014). Studije obiteljskih procesa odvijaju se posljednjih desetljeća kroz sve rafiniraniji metodološki pristup, u kojima se obitelj izučava kako pojedinačno, primjerice interakciju roditelj - dijete, tako i cjelovito uključujući njezinu interakciju s okolinom. Istraživanja su najčešće transverzalnog okvirnog nacrta, a longitudinalnih je vrlo malo. Tako o postojanosti ili promjenama u funkcioniranju i interakcijama obitelji možemo površno govoriti. Dosadašnja istraživanja najčešće pomažu u određivanju intervencijskih mogućnosti doprinoseći optimalnom i kvalitetnijem funkcioniranju, a mogući pozitivni učinci reflektiraju se i na zdravlje članova obitelji. Problemski promatrano, istraživanja su često usmjerena na ispitivanje: promjena u strukturi obitelji, problema „razdvojenih“ i jednoroditeljskih obitelji, nasilja u obitelji, roditeljskih kompetencija (Zloković, Nenadić-Bilan, 2012), kako bi se pronašle mogućnosti podizanja kvalitete obiteljskog života i osnaživanja obitelji. U tom kontekstu, u ovome radu polazi se sa stajališta nekih pitanja o obiteljskoj komunikaciji i koheziji radi pronalaženja konceptualnih 
modela u podizanju razine pozitivnih obiteljskih odnosa i zdravog razvoja djece.

\section{Metodologija}

\section{Problem i cilj istraživanja}

Pozitivni odnosi, obiteljska kohezija, prihvatljiva razina fleksibilnosti kao odgovor na nove situacije i promjene neki su od mogućih zaštitnih čimbenika u funkcioniranju obitelji i pretpostavka boljih međusobnih odnosa. Jedan od osnovnih ciljeva istraživanja je upoznati i istražiti funkcioniranje obiteljske zajednice - obiteljsku komunikaciju i koheziju na temelju kojih se procjenjuje i relevantnost pedagoških odgojnih postupaka za optimalan razvoj djece. Poznavanje rizičnih ali i zaštitinih čimbenika omogućuje kreiranje uvjeta za poticanje pozitivnih odnosa i osnaživanja obitelji, što bi moglo pridonjeti i spriječavanju ili reduciranju mogućih rizičnih i asocijalnih ponašanja.

\section{Metoda i mjerni instrumenti}

U istraživanju smo koristili konceptualni okvir za mjerenje obiteljskog sistema funkcioniranja preko tri osnovne dimenzije - kohezije, fleksibilnosti, oblika i vještina komunikacije u obitelji (Circumplex Model of Marital and Family Systems, Olson i sur., 2003) (Zloković, 2012). Ovaj model nalazimo u širokom spektru suvremenih istraživanja, a smatra se uspješnim u nadilaženju mnogih različitosti društvenih i humanističkih znanosti te uvažava različitosti današnjih obitelji (Zabriskie, McCormick, 2001).

Sa tendencijom da se model za mjerenje obiteljskog sustava učini što učinkovitijim, Olson uvodi i trodimenzionalni Cirkumplex model. Za testiranje pretpostavki modela kreirani su instrumenti samoprocjene i skale za rangiranje (FACES II i FACES III). Zanimljivo je što studije u kojima su primjenjeni ovi instrumenti pokazuju da su dimenzije kohezivnosti i fleksibilnosti kurvilinearne, a ne prelinearne (Olson, 1991). Pretpostavke koje se izvode iz osnovnog Cirkumplex modela su da obitelji sa balansiranom (uravnoteženom) razinom kohezivnosti i fleksibinosti primjerenije funkcioniraju od obitelji sa ekestremnom ili neuravnoteženom razinom. 


\section{Uzorak}

Istraživanje se provodilo u dvije vremenske serije 2010. i 2016. godine. U prvoj seriji uzorak $(\mathrm{N}=357)$ su predstavljali adolescenti učenici 6. i 7. razreda na 20 primarno selekcioniranih jedinica (osnovnih škola). Populaciju ispitanika 2016. godine predstavljaju učenici petnaestogodišnjaci $(\mathrm{N}=100)$ polaznici drugih razreda četiri srednje škole u gradu Rijeci. Uzorak je prigodan.

\section{Postupak prikupljanja podataka}

Analiza dosadašnjih istraživanja o relevantnim aspektima funkcioniranja obitelji u svijetu i kod nas pokazala je da ispitivanje procjene adolescenata pružaju točne, vjerodostojne i pronicljive informacije o obitelji i da su adolescenti vrlo realni procjenjivači obiteljskog stanja (Karavasilis i sur. 2003; Lozović i sur. 1992. i dr).

Rezultati samoprocjene ispitanika obiteljske kohezivnosti prikupljeni su preko skale FACES III. Instrument se sastoji od sedam dimenzija kohezije: emocionalna povezanost, obiteljska uključenost, obiteljski odnosi, odnosi roditelj - dijete, unutarnje granice - vrijeme, emocionalni i fizički prostor. Čestice su ispitanici procjenjivali od 1 uopće se ne odnosi na mene, 2 - nedostatno, 3 - ograničeno, 4 - povremeno, 5 - ponekad, 6 - dobro, 7 - visoko, 8 - naglašeno, 9 - vrlo visoko, 10 - u potpunosti se odnosi na mene.

Skala za ispitivanje komunikacije u obitelji sastoji se od devet čestica - vještina slušanja, govornih vještina, iskazivanja osjećaja, jasnoće verbalnih i neverbalnih poruka, dosljednosti u iskazivanju poruka, međusobni obzir i poštovanje. Ispitanici su čestice skale procjenjivali na način:1 - uopće se ne odnose na mene i roditelje, 2 - rijetko, 3 - ponekad, 4 - često, 5 - gotovo uvijek, 6 - uvijek se odnosi (Zloković, 2012).

\section{Obrada rezultata}

Podaci istraživanja druge vremenske serije su obrađeni IBM SPSS 20.0 programom (Statistical Package for the Social Sciences).

U radu se navode neki rezultati koji se odnose na dvije dimenzije modela - obiteljsku komunikaciju i koheziju. 


\section{Rezultati i rasprava}

Kao jedna od tri dimenzije modela, obiteljska komunikacija smatra se podupirućom dimenzijom obiteljske funkcionalnosti. Procjenjuje se u odnosu na činjenice koliko obitelj kao grupa posjeduje vještine slušanja, jasnoću govora, mogućnost praćenja kontinuiteta razgovora, uvažavanje i poštivanje drugih naspram isticanja sebe. Komunikacija se smatra ključnim čimbenikom koji omogućava da obitelj ostvari kohezivnost i fleksibilnost. U mnogim ispitivanjima nalazi se kako uravnoteženi - izbalanirani sustavi imaju vrlo dobru komunikaciju u odnosu na neizbalansirane sustave (Gorall i sur., 2006.).

Rezultati deskriptivne statistike samoprocjene ispitanika o komunikaciji u obitelji ukazuju da je najniže procijenjena sedma čestica skale: Jesu li tvoji roditelji učestalo nedosljedni u svojim verbalnim ili neverbalnim porukama, koja upućuje na roditeljsku nedosljednost $(\mathrm{M}=3,27 ; \mathrm{SD}=1,34)$, što kod djece može izazvati zbunjenost, modeliranje ponašanja i neželjenog načina komunikacije. Čestica skale Poštuju li te tvoji roditelji i imaju li obzira prema tebi najviše je rangirana $(\mathrm{M}=5,53$; $\mathrm{SD}=0,93$ ), što je optimističan podatak u poticanju međusobnog povjerenja i pozitivnih odnosa u obitelji. Ispitanici smatraju i da ih roditelji gotovo uvijek slušaju pozorno $(\mathrm{M}=5,25 ; \mathrm{SD}=0,93)$, kao i da su roditelji skoro uvijek empatični i razumiju osjećaje i probleme djece $(\mathrm{M}=4,58 ; \mathrm{SD}=1,22)$. Dvadeset posto ispitanika, ipak, smatra da su njihovi roditelji rijetko ili uopće nisu empatični, te ne razumiju osjećaje i probleme vlastitog djeteta (vrijednosti skale 1- uopće se ne odnosi na mene, 2- nedostatno, 3ograničeno).

Iako odgovori velikog dijela ispitanika upućuju na kvalitetnu komunikaciju između njih i roditelja, valja obratiti pozornost i na one ispitanike čiji odgovori upućuju na neželjenu razinu komunikacije, primjerice na ispitanike čiji su roditelji nedosljedni u iskazivanju verbalnih i neverbalnih poruka. I prema rezultatima istraživanja iz prve vremenske serije 2010. godine, veliki broj ispitanika $(24,5 \%)$ procjenjuje da im je samo ponekad jasno kad u obitelji netko o njima govori "samome sebi" ("glasna" /intra/komunikacija roditelja) ili kada to čini sa drugim osobama, jer im se niti u jednoj situaciji roditelji ne obraćaju neposredno $\mathrm{M}=3.19$; SD 1.58) (Zloković, 2012).

Rezultati ispitivanja komunikacije roditelja i djece iz druge vremenske serije u cijelosti su prikazani u Tablici 1 . 


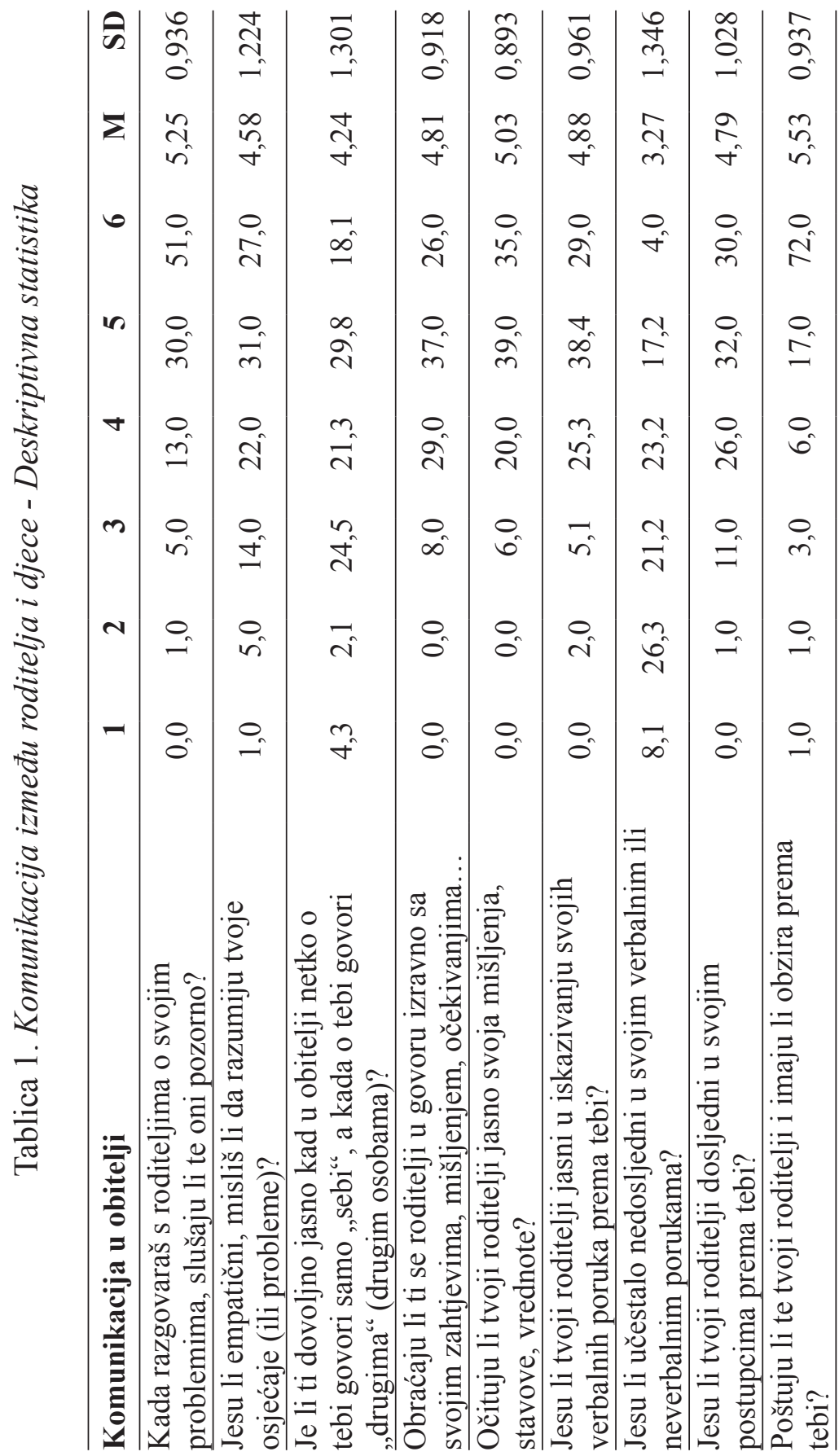


Iako na različitim vremenskim uzorcima, rezultati obje vremenske serije upućuju na dvije skupine ispitanika, i to onih koji visoko procjenjuju relevantne dimenzije kvalitetne komunikacije, dok se na suprotnom kraju nalaze ispitanici koji te iste dimenzije procjenjuju na niskoj i nižoj razini. Slično se odnosi i na dimenzije obiteljske kohezije.

Obiteljska kohezivnost definira se kao emocionalna povezanost koju članovi obitelji imaju jedni prema drugima (emocionalne veze, granice, koalicije, vrijeme, prostor, prijatelji, donošenje odluka, zajednički interesi, rekreacija-razonoda). Istraživanje obiteljske kohezije usmjereno je na analizu načina na koji obiteljski sustavi balansiraju razdvojenost svojih članova nasuprot zajedništvu. Autori izdvajaju četiri razine kohezivnosti: razdvojenost (vrlo niska kohezivnost); odvojenost (niska do prosječna kohezivnost); povezanost (prosječna do visoka kohezivnost); umreženost (vrlo visoka kohezivnost). Za optimalno funkcioniranje obitelji najpoželjnijima smatra se centralna kohezivnost (odvojenost i povezanost) koja ukazuje na dobru izbalansiranost obiteljskog sustava. U ekstremnim razinama (razdvojenost i umreženost) evidentna je neizbalansiranost obiteljskog sustava, što implicira nedostatak samostalnosti ili pretjeranu otuđenost članova obitelji. Ekstremne ili neizbalansirane razine općenito smatraju se problemnim za odnose u obitelji i s posljedicama kroz dulje vrijeme (Olson, 2000; Olson i Gorall, 2006). U uravnoteženom području kohezije (odvojeni i povezani) članovi obitelji mogu da iskuse i balansiraju obje razine. U stanju su da istovremeno budu i nezavisni ali i povezani sa obitelji. Ukoliko su razine kohezije vrlo visoke (umreženi sustavi), postoji previše suglasnosti u obitelji a premalo nezavisnosti i prostora individualizacije. Na suprotnoj strani (razdvojeni sustavi) članovi obitelji "rade samo ono što hoće". Prisutna je vrlo ograničena razina privrženosti, kao i obveze prema obitelji. Izbalansirani bračni i obiteljski sustavi (odvojeni i povezani) skloni su boljem funkcioniranju tijekom životnog ciklusa. U obiteljima gdje je kohezivnost prosječna do visoka (povezani tip obitelji) uočava se visoka emocionalna bliskost i međusobna odanost. Vrijeme koje provode zajedno važnije im je od vremena kojeg provode sami. Imaju različite ali i zajedničke prijatelje. Zajednički interesi su im jednaki sa nekim pojedinačnim aktivnostima (Olson, 2000, 1991, 1986). Neizbalansirane razine kohezije pojavljuju se kao ekstremni ili vrlo nisko (nepovezani) ili vrlo visoko (umreženi). Nepovezani ili razdvojeni tipovi obitelji često imaju ekstremnu emocionalnu odvojenost a sukladno tome međusobno su malo povezani i postoji osobna razdvojenost i nezavisnost. U 
obitelji često svatko radi isključivo "svoje" poslove, preferira razdvojenost vremena, prostora, interesa, kao što se i ne mogu osloniti jedni na druge s obzirom na podršku ili rješavanje problema. S obzirom na umreženi tip, uočava se ekstremna razina emocionalne bliskosti i pretjerana razina odanosti. Posebno su ovisni jedni o drugima i međusobno reaktivni. Nedostaje osobne odvojenosti a privatnog prostora dozvoljeno je vrlo malo. Energija pojednica uglavnom se usmjerava prema obitelji i postoji samo nekoliko vanjskih prijatelja. Prema Cirkumpleks modelu, ekstremne razine kohezije imaju tendenciju rizičnosti za članove obitelji i njihov razvoj tijekom životnog ciklusa. Iako je teško odrediti "uspješnu" razinu kohezivnosti ekstremne razine (posebno ukoliko traju dulje vrijeme), smatraju se neželjenima i rizičnima.

Ispitanici su čestice skale obiteljske kohezivnosti procjenjivali ovako: 1. uopće se ne odnosi na mene, 2. nedostatno, 3. ograničeno, 4. povremeno, 5. ponekad, 6. dobro, 7. visoko, 8. naglašeno, 9. vrlo visoko, 10. u potpunosti (Tablica 2). Rezultati su pokazali da je najniže procijenjena šesta čestica ili dimenzija vremena - Provodiš li sa svojim roditeljima dovoljno vremena? $(\mathrm{M}=6,94 ; \mathrm{SD}=2,29)$. Najviše rangirana je obiteljska odanost $(\mathrm{M}=8,48 ; \mathrm{SD}=1,73)$. I preostale dimenzije veliki broj ispitanika je procijenio visoko: naglašena međusobna povezanost $(\mathrm{M}=8,29 ; \mathrm{SD}=1,90)$, međusobna obiteljska uključenosti i interakcije $(\mathrm{M}=7,70 ; \mathrm{SD}=2,00)$, povezanost roditelja i ispitanika $(\mathrm{M}=8,15 ; \mathrm{SD}=2,12)$, zajedničko vrijeme $\mathrm{u}$ istom prostoru, razgovoru i rješavanju problema $(\mathrm{M}=7,54 ; \mathrm{SD}=2,59)$.

Zajednički prostor boravka, razgovora i rješavanja problema statistički je značajno povezan sa zadovoljstvom komunikacijom $\mathrm{s}$ roditeljima kod ispitanih adolescenata $(\mathrm{P}<0,05 ; \mathrm{P}=0,014, \mathrm{r}=-, 246)$, što bi se moglo pokazati korisnom informacijom za roditelje koji ponekad suočeni s paradoksima suvremenog doba - mogu ovu činjenicu zanemariti.

Između varijabli obiteljske kohezije i zadovoljstva komunikacijom s roditeljima postoji statistički značajna povezanost, što vjerojatno znači da su adolescenti iz kohezivnijih obitelji i zadovoljniji komunikacijom s roditeljima $(\mathrm{P}<0,01, \mathrm{P}=0,000, \mathrm{r}=-, 477)$. 


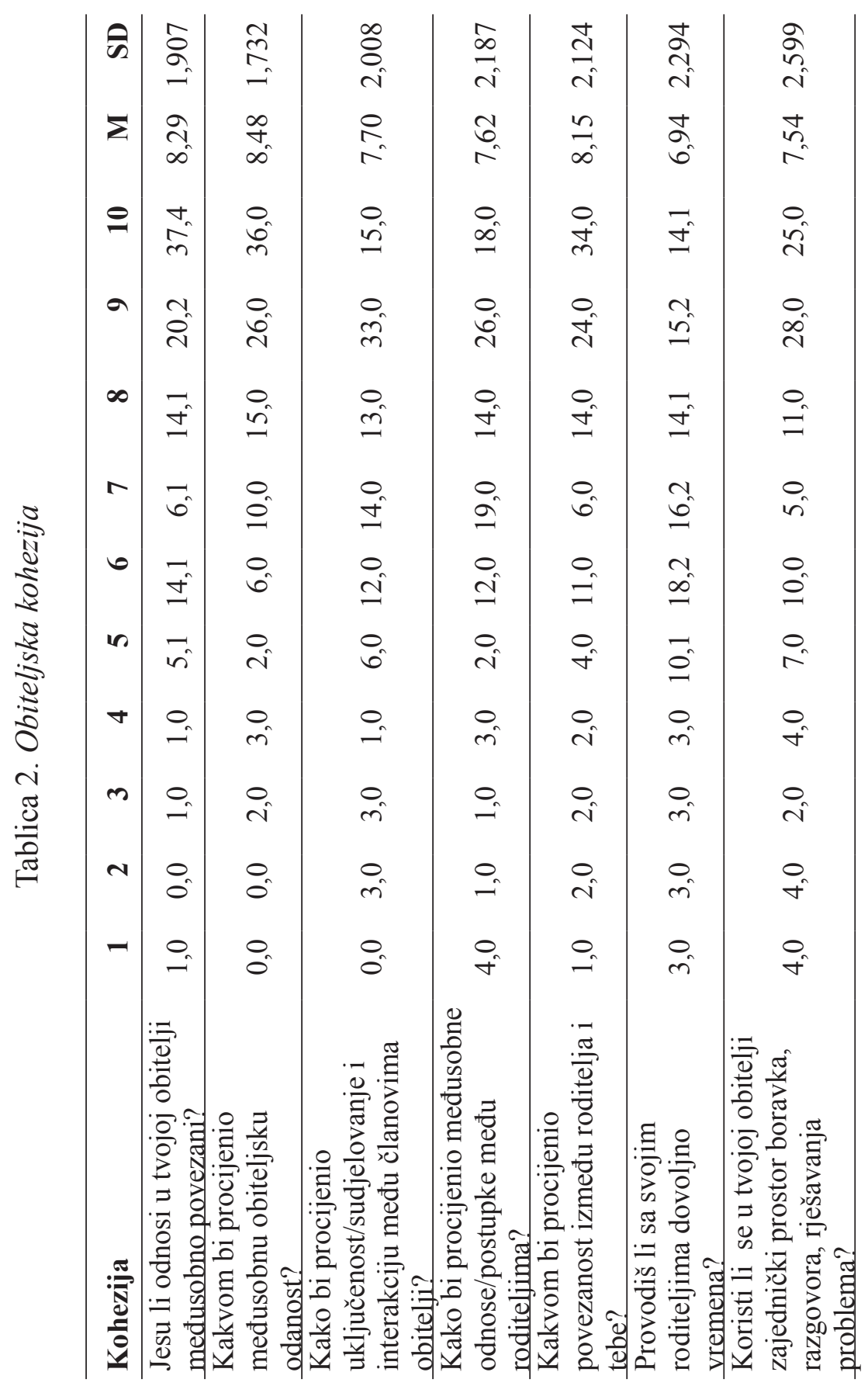


I prema rezultatima o obiteljskoj koheziji iz prve studije 2010. godine (Zloković, 2012), razvidna su dva ekstremna kraja. Na jednoj strani su adolescenti čiji odgovori upućuju na vrlo nisku obiteljsku koheziju i razdvojenost, što pripada skupini mogućeg umanjenog razvoja i rizičnih ponašanja, a na drugom kraju uočava se ekstremna razina od visoke emocionalne bliskosti i odanosti članova obitelji do vrlo visoke razine kohezije (umreženi). Kod "umreženih" obitelji previše je suglasnosti a premalo nezavisnosti i individualizacije. Visoki rezultati emocionalne povezanosti upućuju na mogući otežani razvoj neovisnosti osobe, a niski rezultati na moguće kaotične odnose u obitelji. S obzirom na rezultate, moguće je govoriti i o "centripetalnim" obiteljima koje imaju tendenciju da su "vrlo teške" pri emancipiranju djeteta, kao i o "centrifugalnim"obiteljima koje pokušavaju to učiniti i prije nego što je dijete kao individua (kompletno) spremno. Beavers i Hampson (2000) ekstremno preuranjeno «izbacivanje« djeteta iz bliskih obiteljskih odnosa smatraju rizičnim budući se kod djece nalazi mnogo više pojave anksioznosti, depresije.

Polazeći sa humano razvojnih stajališta, realno je očekivanje da obje skupine ispitanika i roditelja budu uključene u programe pedagoške i druge vrste edukacijske i savjetodavne pomoći s ciljem izbjegavanja ili barem smanjivanja rizika kojima su izložene, kao i sa ciljem poticanja pozitivne komunikacije i osnaživanja obitelji.

\section{Zaključna rasprava}

Odnosi uspostavljeni u obitelji utječu na razvoj djeteta i prenose se kao model ponašanja tijekom čitavog života. U kontekstu današnjeg promijenjenog psiho-socijalnog mikro i makro sustava nužan je rad na osnaživanju obiteljskih odnosa, programa podrške u razvijanju roditeljskih kompetencija, poboljšanju fizičke i psihičke dobrobiti djece i obitelji, poticanja pozitivnih raspoloženja i emocija, samopercepcije, autonomije osobnosti i promocije pozitivnih socijalnih ponašanja. Istraživanja obitelji uglavnom su fokusirana na obitelji s problemima i na pitanje zbog čega obitelj ne uspijeva $u$ ispunjavanju svojih funkcija. Malo je pristupa fokusiranih na obitelj koje dobro funkcioniraju i koji bi pomogli da se nađe odgovor na pitanje kako obitelj učiniti uspješnijom. Istraživanje obiteljske komunikacije i kohezije, te spoznaje koje iz oba vremenski i uzorkom različita istraživanja slijede, u prilog su podršci i pozitivnim nastojanjima da se osnaži suvremena obitelj i život u obitelji učini humanijim. Ponekad 
s obzirom na odnose u obitelji, posebice komunikaciju i koheziju, čini se kao da su djeca izgubila svoje mjesto u obitelji ili pak da je izražena pretjerana povezanost i zavisnost ("umreženi", "zapleteni u obitelj!”), kao i visoko izražena lojalnost članova obitelji.

Nađena visoka razina na nivou kohezivnosti upućuje na razvijanje zavisničkih, zatvorenih i manje istraživačkih tendencija kod djece u razvoju kao pogodno tlo za okolinsku manipulaciju. Visoki rezultati na emocionalnoj povezanosti mogu ukazivati na otežani razvoj buduće neovisnosti individue, a niska povezanost na moguće kaotične odnose u obitelji. Kaotični odnosi čine život u mnogim obiteljima stresnim i konfliktnim. S obzirom na moguće posljedice možemo govoriti i o rizičnim obiteljima. Cilj našeg istraživanja nije bio ulaženje u kauzalitet odnosa, već identificiranje obiteljske prakse koja na skali kohezivnosti pokazuje da veliki broj adolescenata i roditelja treba preventivne i intervencijske aktivnosti kako bi uspostavili bolju ravnotežu u međusobnim odnosima i što bi moglo pridonjeti optimalnijem funkcioniranju obitelji.

I na skali za ispitivanje komunikacije roditelj - dijete pokazuju se također dvije ekstremne skupine ispitanika. Na jednoj strani nalaze se ispitanici čiji odgovori ukazuju na neprimjerenu komunikaciju u obitelji, što bi kod djece moglo ostaviti dojam da nisu «vrijedni roditeljeva truda i vremena» te osjećaj zbunjenosti i nesigurnosti u svoje postupke ukoliko su izloženi nejasnim porukama koje od roditelja dobivaju. Na suprotnom kraju skale nalaze se ispitanici koji sa svojim roditeljima komuniciraju na visokoj razini, što je jedna od pretpostavki koja pridnosi i visokim rezultatima o kohezivnosti.

Istraživanje koje je provedeno, unatoč već ekstenzivne primjene u svijetu, u nas predstavlja nagovještaj usklađenog istraživačkog rada sa pedagoškom praksom. Ispitivanje predstavlja jedan od novijih pristupa u izučavanju kompleksnosti obiteljskih odnosa. Vjerujemo da dobiveni rezultati proizašli iz znanstvene studije "Pedagoški aspekti odnosa u obitelji" (Zloković, 2007-2016) pridonose pedagoškoj znanosti kao i praksi, a upućuju nadalje i na zaključak o potrebi longitudinalne primjene modela $\mathrm{u}$ utvrđivanju razlika $\mathrm{u}$ vremenskim serijama, te na potrebu intenziviranja različitih pristupa modelima i nadasve socijalnim i pedagoškim programima namijenjenim osnaživanju obitelji kao temeljne i najvažnije socijalne jedinice. 


\section{FAMILY EMPOWERMENT THROUGH THE PROMOTION OF POSITIVE RELATIONSHIPS AND A FAMILY COHESION}

\section{SUMMARY}

Abstract: The results of multidisciplinary studies show that mutual connection, support, a positive family atmosphere, and the manner and level of communication within the family and wider social environment could encourage, but also challenge and constrain the development of personality. The paper starts from the standpoint of the questions about family communication and cohesion in order to encourage further opportunities to strengthen the family, thus finding the conceptual models in raising the level of positive family relationships and healthy development of children.

Results of the research, which was conducted in 2010 and 2016 as a part of the scientific-research project "Pedagogical Aspects of Family Relationships" (Zloković, 2012) show unbalanced family relationships by using the longitudinal application of Olson 's model as a conceptual model for measuring the family system. There is extremely high and extremely low connectivity on the scale of family cohesiveness. High scores on emotional connection may indicate a hampered development of future individual independence, while a low correlation indicates chaotic family relationships. The scale for testing a parent - child communication also shows that there are two extreme groups of respondents. On one side there are respondents whose answers indicate inadequate, ambiguous, ambivalent communication in the family. On the other side, there are respondents who communicate with their parents at a high level, which is one of the assumptions that contributes to high scores on the scale of cohesiveness.

The obtained results contribute to pedagogical science, especially to the family pedagogy and practice in determining preventive and intervention activities aimed at optimal functioning and empowerment of families.

Key words: family cohesion, communication, family relationships, family empowerment. 


\section{Literatura}

Beavers, W.R., Hampson, R. (2000). The Beavers Systems Model of Family Functioning. Journal of Family Therapy 22 (2), 128-143.

Gorall, D.M., Tiesel, J., Olson, D.H. (2006.): FACES IV: Development and Validation, Minnesota: University of Minnesota.

Janković, J. (2008.): Obitelj u fokusu, Zagreb: Etcetera.

Karavasilis, L., Doyle, A.B., Markiewitz, D. (2003). Associations Between Parenting Styleand Attachment to Mother in Middle Childhood and adolescence. International Journal of Behavioral Development 27 (1)153-164.

Lozović, N., Knežević, G., Mitić, M., Berger, J. (1992). Mogućnosti upitničkog ispitivanja dimenzija porodičnog funkcionisanja. Institut za psihološka istraživanja, Psihološka istraživanja 5 (1) 63-84.

Milić, A. (2010). Porodica i izazovi globalne transformacije, u: Milić, A. i sur. (ur). Vreme i porodica, Sociološka studija o porodičnoj transformaciji u savremenoj Srbiji, Beograd: Čigoja štampa, Insitut za sociološka istraživanja, 13-32.

Olson, D.H. (1986). Circumplex Model VII: Validation Studies and FACES III, Family Processes, 25 (2) 337-351.

Olson, D.H. (1991). Three dimensional (3-D) Circumplex Model, ST.Paul, MN: Family Social Science, University of Minnesota.

Olson, D.H., DeFrain, J. (1994). Marriage and family. Diversity and strengths, Mountain View, CA: Mayfield.

Olson, D.H. (2000). Circumplex Model of Marital and family Systems, Journal of Family Therapy, 22 (2)144-167.

Olson, D.H., Gorall, D.M. (2003). Circumplex Model of Marital and family Systems, u: Walsh, F. (ur), Normal Family Processes, 514-547.

Olson, D.H., Gorall, D.M. (2006).FACES IV \& the Circumplex Model, Minnesota: University of Minnesota.

Rosić, V., Zloković, J. (2002). Prilozi obiteljskoj pedagogiji, Rijeka: Filozofski fakultet, Odsjek za pedagogiju.

Vrcelj, S., Zloković, J. (2004). Pedagoški vidiki razvoja in spodbujanje odgovornosti. Pedagoška obzorja - Didactica Slovenica, 1, 38-52.

Zabriskie, R.B., McCormick, B.P. (2001). The Influences of Family Leisure Patterns on Perception of Family Functioning, Family Relations. Interdisciplinary Journal of Applied Family Studies 50 (3) 66-74.

Zloković, J. (2007). Suvremene obitelji između tradicionalnih i virtualnih odnosa, u: Previšić, V.; Šoljan, N. N.; Hrvatić, N. (ur.), Pedagogija 
prema cjeloživotnom obrazovanju $i$ društvu znanja, Zagreb : Hrvatsko pedagogijsko društvo, 761-770.

Zloković, J. (2012). Obiteljska kohezija i pozitivna komunikacija. Školski vijesnik, Časopis za pedagoška i školska pitanja, 61 (3) 265-288.

Zloković, J., Nenadić-Bilan, D. (2012). Neke odrednice zadovoljstva u obnašanju roditeljske uloge u odnosu na odabir odgojnih postupaka, Istraživanje pedagoških aspekata odnosa u obitelji. Školski vijesnik, Časopis za pedagoška i školska pitanja, 61 (1-2) 191-210.

Zloković, J. (2014). Kvaliteta života djece i mladih u kontekstu obiteljskih odnosa. V. Međunarodna naučno-stručna konferencija-Unapređenje kvalitete života djece i mladih / dr.sc. Milena Nikolić (ur.). Tuzla : Edukacijsko-rehabilitacijski Univerzitet u Tuzli i Udruženje za podršku i kreativni razvoj djece i mladih, 2014. 28-39. (objavljeno pozvano predavanje, međunarodna recenzija).

Zuković, S. (2012). Porodica kao sistem - funkcionalnost $i$ resursi osnaživanja, Novi Sad: Pedagoško društvo Vojvodine. 